\title{
Penerapan Metode Diskusi Simposium dalam Pembelajaran Sosiologi untuk Meningkatkan Motivasi Belajar Siswa Kelas X.B SMA Negeri 2 Baebunta Kab. Luwu Utara
}

\author{
Nasriadi \\ Pendidikan Sosiologi, Universitas Pattimura (Unpatti) \\ Email: ari.smc.23@gmail.com
}

\begin{abstract}
The application of the symposium discussion method in the sociology learning the subject of socialization to improve learning motivation of class X students. Baebunta 2 High School 2 District. North Luwu. Thesis, Faculty of Teacher Training and Education, University of Muhammadiyah Makassar. This study was a classroom action research conducted in class X of Baebunta 2 High School, Kab. Luwu Utara and aims to increase learning motivation through the method of symposium discussion. The subjects of this study were class X students of Baebunta 2 High School 2 in the academic year 2010/2011 which amounted to 36 people. Data collection was carried out using qualitative and quantitative analysis. Based on the initial survey the completeness of the test scores before the implementation of the action there were only 23 students. The results achieved after learning using the symposium discussion method, namely in the first cycle with a value that reached completeness was 33 people, while in the second cycle the evaluation value was all completed, as many as 36 students. Viewed from the observations of students that from the first cycle the average percentage of students' learning motivation is from $62.9 \%$ increasing in cycle 2 to $91.6 \%$.
\end{abstract}

Keywords: Application, Discussion, Sociology

Abstrak. Penerapan metode diskusi simposium dalam pembelajaran sosiologi pokok bahasan sosialisasi untuk meningkatkan motivasi belajar siswa kelas X.B SMA Negeri 2 Baebunta Kab. Luwu Utara. Penelitian ini adalah penelitian tindakan kelas yang dilaksanakan pada kelas X SMA Negeri 2 Baebunta, Kab. Luwu Utara dan bertujuan untuk meningkatkan motivasi belajar melalui metode diskusi simposium. Subjek penelitian ini adalah siswa kelas X.B SMA Negeri 2 Baebunta tahun ajaran 2010/2011 yang berjumlah 36 orang.Pengambilan data dilakukan dengan menggunakan analisis kualitatif dan kuantitatif. Berdasarkan survei awal ketuntasan nilai ujian sebelum pelaksanaan tindakan hanya terdapat 23 siswa. Hasil yang dicapai setelah pembelajaran dengan menggunakan metode diskusi simposium yaitu pada siklus I dengan nilai yang mencapai ketuntasan adalah 33 orang, sedangkan pada siklus II nilai evaluasi semuanya tuntas, sebanyak 36 siswa. Dilihat dari observasi siswa bahwa dari siklus 1 persentase rata-rata motivasi belajar siswa yaitu dari 62,9\% meningkat pada siklus 2 menjadi $91,6 \%$.

Kata Kunci: Penerapan, Diskusi, Sosiologi

\section{PENDAHULUAN}

Pembukaan Undang-Undang Dasar Negara Republik Indonesia Tahun 1945 menyatakan bahwa "melindungi segenap bangsa dan seluruh tumpah darah Indonesia dan untuk memajukan kesejahteraan umum, mencerdaskan kehidupan bangsa, dan ikut 
melaksanakan ketertiban dunia berdasarkan kemerdekaan, perdamaian abadi, dan keadilan social. Untuk mewujudkan tujuan nasional tersebut, pendidikan di sekolah merupakan faktor yang sangat menentukan (dalam Martinis Yamin, 2006: 245). Becker mengungkapkan bahwa pendidikan dan pelatihan merupakan investasi terpenting dalam mengembangkan sumber daya manusia, selain itu (dalam Martinis Yamin, 2006: 245) Jones menjelaskan bahwa pendidikan menjadi salah satu fungsi terbesar dan terpenting bagi pemerintah dalam pembangunan anak bangsanya.

Kenyataannya di kelas bahwa pada umumnya keterlibatan siswa sangat kurang dalam proses belajar mengajar, guru lebih dominan dalam memberikan pengajaran, memberikan ceramah yang bisa membuat siswa menjadi jenuh, bosan, bahkan bermainmain dalam belajar, siswa kurang termotivasi dalam belajar, tidakmemperhatikan apa yang dijelaskan oleh guru, terkadang ada siswa yang mempunyai potensi dan mempunyai gagasan tersendiri. Namun, tidak tersalurkan akibat sifat guru yang monoton dalam mengajar, sehingga melihat fenomena tersebut di atas, otomatis tujuan pendidikan nasional tidak akan tercapai, begitu pula dengan sila ke-4 pancasila, jauh dari harapan.

Alasan pentingnya diskusi simposium diterapkan dalam kelas karena adanya alasan bahwa keterlibatan siswa yang kurang dalam kegiatan pembelajaran. Seperti halnya pada siswa Siswa Kelas X.B SMA Negeri 2 Baebunta, Kab. Luwu Utara, belajar dan pembelajaran di kelas terlihat bahwa banyaknya potensi yang dimiliki oleh siswa yang tidak tersalurkan akibat pembelajaran di kelas hanya bersifat ceramah saja, padahal siswa di SMA Negeri 2 Baebunta, Kab. Luwu Utara yang heterogen, jumlah siswa 36 orang dimana 13 orang diantaranya mempunyai nilai yang masih dalam kategori belum tuntas, dilihat dari KKM yaitu 65 pada siswa kelas X.B SMA Negeri 2 Baebunta, Kab. Luwu Utara, semester ganjil tahun ajaran 2010/2011. Sangat baik untuk melakukan Sosialisasi agar mereka saling menerima perbedaan tersebut. Maka salah satu cara yang dapat dilakukan oleh guru dalam kaitan ini adalah memberikan kesempatan kepada siswa untuk berdiskusi. Melalui diskusi kelompok simposium diharapkan dapat mengekspresikan pikirannya, tujuan pendidikan jauh lebih efektif tercapai jika dilakukan melalui diskusi simposium. Tujuan-tujuan tersebut adalah tujuan-tujuan dalam hal keterampilan serta nilai dan sikap. Misalnya keterampilan berbicara, mengungkapkan pendapat, keterampilan berbahasa, sopan santun dalam mengajukan perbedaan pendapat, serta keterampilan berinteraksi sosial, akan jauh lebih efektif pencapainnya jika dilakukan melalui diskusi simposium. Berdasarkan pemaparan di 
atas, penulis merumuskan judul yaitu "Penerapan metode diskusi simposium pada pembelajaran sosiologi pokok bahasan sosialisasi untuk meningkatkan motivasi belajar siswa kelas X.B SMA Negeri 2 Baebunta, Kab. Luwu Utara."

\section{LANDASAN TEORI}

\section{Pendidikan Sosiologi}

Ditinjau dari segi etimologi istilah sosiologi pendidikan terdiri atas dua perkataan yaitu sosiologi dan pendidikan. Maka sepintas saja telah jelas bahwa sosiologi pendidikan itu yang menjadi masalah sentralnya ialah aspek-aspek sosiologi di dalam pendidikan. Menurut H. P Fairlic (dalam Abu Ahmadi, 2007) dikatakan " sosiologi pendidikan adalah sosiologi yang diterapkan untuk memecahkan masala-masalah pendidikan yang fundamental. Menurut E. George Payne (dalam Abu Ahmadi, 2007) yang disebut sebagai bapak sosiologi pendidikan seperti halnya A. Comte sebagai bapak sosiologi menekankan, bahwa didalam lembagalembaga, kelompok-kelompok sosial, proses sosial, terdapatlah apa yang dinamakan Relationship atau interaksi sosial dimana dalam interkasi sosial itu individu memperoleh dan mengorganisasi pengalaman-pengalamannya yang inilah yang menjadi prinsip-prinsip atau aspek dari sosiologi pendidikan.

\section{Pengertian Belajar dan Pembelajaran}

Menurut Arthur T. Jersild, (dalam Syaiful Sagala, 2006: 12) Belajar adalah perubahan atau membawa akibat perubahan tingkah laku dalam pendidikan karena pengalaman dan latihan atau karena mengalami latihan. Dalam mengalami itu anaka belajar terus menerus antara anak didik dengan lingkungannya secara sadar dan sengaja. Sedangkan Belajar menurut Morgan ((Syaiful Sagala, 2006: 13) adalah setiap perubahan yang relatif menetap dalam tingkah laku yang terjadi sebagai suatu hasil dari latihan atau pengalaman. Belajar menurut Margaret E. Bell Gredler (dalam Sahabuddin, 2003: 84) adalah proses orang memperoleh berbagai kecakapan, keterampilan, dan sikap.

\section{Metode-Metode Pembelajaran}

Adapun metode-metode mengajar menurut Abu Ahmadi (2005: 53) diantaranya:

a. Metode Ceramah 
yaitu suatu metode di dalam pendidikan dan pengajaran di mana cara menyampaikan pengertian-pengertian materi pengajaran kepada anak didik dilaksanakan dengan lisan oleh guru dalam kelas.

b. Metode Tanya Jawab

ialah suatu metode di dalam pendidikan di mana guru bertanya sedangkan siswa mejawab tentang bahan materi yang ingin diperolehnya.

c. Metode Diskusi

Metode diskusi ialah suatu kegiatan kelompok dalam memecahkan masalah untuk mengambil kesimpulan. Menurut Suryosubroto (2002: 179), diskusi adalah suatu percakapan ilmiah oleh beberapa orang yang tergabung dalam satu kelompok untuk saling bertukar pendapat tentang suatu masalah atau bersama-sama mencari pemecahan mendapatkan jawaban dan kebenaran atas suatu masalah. Prasaran menyiapkan tulisan yang dibagi-bagikan kepada peserta, dan diadakan sanggahan dari ahli tertentu yang disebut penyanggah utama. Pendengar dapat memberikan pandangan umum dan pertanyaan sesudah penyanggah utama menurut Martinis Yamin (2006: 167).

\section{Hakikat Pembelajaran Sosialisasi}

1. Pengertian Sosialisasi

a. Havighurst dan Heugarten (dalam Abu Ahmadi, 2007:153) bahwa proses sosialisasi adalah proses belajar. Meskipun sosialisasi karapkali disamaartikan dengan proses belajar, tetapi bebrapa ahli mengartikan sebagai proses belajar yang bersifat khusus.

b. Thomas Ford Hoult (dalam Abu Ahmadi, 2007:153) bahwa proses sosialisasi adalah proses belajar individu untuk bertingkah laku sesuai dengan standar yang terdapat dalam kebudayaan masyarakatnya.

c. R. S Lazarus (dalam Abu Ahmadi, 2007:153) proses sosialisasi adalah proses akomodasi, dengan mana individu menghambat atau mengubah impuls-impuls sesuai dengan tekanan lingkungan, dan mengembangkan pola-pola nilai dan tingkah laku yang baru sesuai dengan kebudayaan masyarakat. 
d. G. H. Mead (dalam Abu Ahmadi, 2007:153) berpendapat bahwa dalam proses sosialisasi itu individu mengadopsi kebiasaan, sikap dan idea-idea dari orang lain, dan menyusunnya kembali sebagai sesuatu sistem dalam diri pribadinya

\section{METODE PENELITIAN}

a. Jenis penelitian ini adalah penelitian tindakan kelas (PTK) di mana data yang didapat adalah data kualitatif dan kuantitatif, persiapan penelitiannya yaitu data pelaksanaan pembelajaran diperoleh dari hasil pengamatan selama pelaksanaan tindakan tiap siklus dengan menggunakan instrumen observasi kegiatan Guru dan siswa pada saat KBM, dikolaborasikan dengan tanya jawab serta penilaian evaluasi siswa.

b. Setting dan Subjek Penelitian

Penelitian ini akan dilaksanakan di SMA Negeri 2 Baebunta, Kabupaten Luwu Utara. Penelitian ini merupakan penelitian tindakan kelas (PTK), adapun jenis tindakan yang akan diteliti yaitu, Motivasi siswa dalam melakukan Diskusi Simposium dan proses serta pengetahuan siswa terhadap materi pelajaran Sosialisasi. Adapun penelitian tindakan kelas ini di khususkan pada kelas X.B pada mata pelajaran sosiologi pokok bahasan Sosialisasi semester I tahun pelajaran 2010/2011.

c. Instrumen Penelitian

Alat yang dugunakan dalam proses pembelajaran di sekolah ini adalah buku pedoman guru dan siswa kelas X SMA serta buku pedoman sosiologi yang relevan digunakan dengan kurikulum KTSP, lembar kerja siswa diserta angket yang dapat mendukung proses pembelajaran agar berjalan efektif dan efesien. Data yang dikumpulkan melalui catatan observasi proses dan aktivitas siswa selama proses kegiatan belajar mengajar berlangsung yang dilakukan sejak awal penelitian siklus pertama sampai dengan siklus terakhir. Catatan Observasi dipergunakan untuk mengetahui peningkatan motivasi belajar siswa, terhadap materi pelajaran pokok bahasan Sosialisasi. Pada bagian Refleksi dilakukan analisis data mengenai proses, masalah dan hambatan yang di jumpai, kemudian dilanjutkan dengan Refleksi dampak tindakan yang dilaksanakan, disini akan dilihat aktivitas siswa selama proses belajar mengajar berlangsung. 


\section{d. Analisis Data}

Data yang diperoleh dari penelitian ini dianalisi melalui observasi dan evaluasi Lembar observasinya menurut Firdaus Zarkasi, (2009: 113), yaitu :

\begin{tabular}{|l|l|l|l|l|l|l|l|}
\hline No. & No. Induk & & \multicolumn{4}{|c|}{ Aspek yang dinilai } & \multirow{2}{*}{ Jumlah Skor } \\
\cline { 4 - 7 } & & & A & B & C & D & \\
\hline 1. & & & & & & & \\
\hline 2. & & & & & & & \\
\hline
\end{tabular}

Keterangan:
A : Kemampuan menyampaikan Informasi
B : Kemampuan mengajukan pertanyaan
$C$ : Kemampuan mengajukan argumentasi
D : Kelancaran berbicara

Skor dan cara penilaian:

3 : Sangat Baik, 2 : Baik, 1 : Kurang Baik.

Data yang di peroleh melalui evaluasi dianalisis Dengan rumus

Nilai $=\underline{\text { (skor perolehan) }}$

(skor maksimun) x 100

Adapun persentase peningkatan hasil belajar, data yang di peroleh melalui evaluasi menurut Zainal Aqib (53: 2008) dianalisis Dengan rumus berikut:

$\mathrm{P}=\frac{\text { postrate }- \text { baserate }}{\text { baserate }} \times 100 \%$

Keterangan :

P : Persentase peningkatan

Postrate : Nilai sesudah diberikan tindakan

Baserate : Nilai sebelum tindakan

Tabel 3.2 Kriteria Persentase depdiknas tahun 1994.

\begin{tabular}{|c|c|c|}
\hline No & Nilai & Kategorisasi \\
\hline 1 & $0-34$ & Sangat rendah \\
\hline 2 & $35-54$ & Rendah \\
\hline 3 & $55-64$ & Sedang \\
\hline 4 & $65-84$ & Tinggi \\
\hline 5 & $85-100$ & Sangat tinggi \\
\hline
\end{tabular}




\section{HASIL PENELITIAN DAN PEMBAHASAN}

Hasil dan analisis data penelitian dibuat berdasarkan data yang diperoleh dari kegiatan penelitian tentang peningkatan motivasi belajar siswa melalui penerapan metode diskusi simposium yang telah dilaksanakan pada siswa kelas X.B SMA Negeri 2 Baebunta, Kab. Luwu Utara, pada saat sebelum penerapan metode diskusi simposium, siklus I ke siklus II dengan menggunakan analisis kualitatif yaitu dari hasil observasi dan kuantitatif yaitu hasil evaluasi.

\section{ANALISIS HASIL EVALUASI}

\section{Siklus 1}

Gambaran ketuntasan belajar siswa kelas X.B SMA Negeri 2 Baebunta, Kab. Luwu Utara, yang diperoleh berdasarkan skor evaluasi hasil belajar pada siklus 1 adalah sebagai berikut:

\begin{tabular}{|c|c|c|c|}
\hline Skor & Kategori & Frekuensi & Persentase \\
\hline $0-64$ & Tidak tuntas & 3 & $8,3 \%$ \\
\hline $65-100$ & Tuntas & 33 & $91,7 \%$ \\
\hline \multicolumn{2}{|c|}{ Jumlah } & 36 & $100 \%$ \\
\hline
\end{tabular}

Dari tabel 1.2 diatas menunjukkan persentase ketuntasan belajar siswa kelas X.B SMA Negeri 2 Baebunta, Kab. Luwu Utara, sebesar 91,7\% atau 33 dari 36 siswa termasuk dalam kategori tuntas dan 8,3\% atau 3 dari 36 siswa termasuk dalam kategori tidak tuntas.

\section{Siklus 2}

Gambaran ketuntasan belajar siswa kelas X.B SMA Negeri 2 Baebunta, Kab. Luwu Utara, yang diperoleh berdasarkan skor hasil belajar adalah sebagai berikut: Tabel. 1.3 Deskripsi Ketuntasan Belajar siswa kelas X.B SMA Negeri 2 Baebunta, Kab. Luwu Utara.

\begin{tabular}{|c|c|c|c|}
\hline Skor & Kategori & Frekuensi & Persentase \\
\hline $0-64$ & Tidak tuntas & - & - \\
\hline $65-100$ & Tuntas & 36 & $100 \%$ \\
\hline \multicolumn{2}{|c|}{ Jumlah } & 36 & $100 \%$ \\
\hline
\end{tabular}


Dari tabel 1.1 diatas menunjukkan persentase ketuntasan belajar siswa kelas X.B SMA Negeri 2 Baebunta, Kab. Luwu Utara, sebesar $100 \%$ atau 36 dari 36 siswa termasuk dalam kategori tuntas dan tidak ada lagi siswa yang termasuk dalam kategori tidak tuntas. Berikut disajikan diangram batang 1.3. tentang ketuntasan hasil belajar sosiologi siswa kelas X.B SMA Negeri 2 Baebunta, Kab. Luwu Utara.

\section{Refleksi siklus I}

Dari tabel 1.2 diatas menunjukkan persentase ketuntasan belajar siswa kelas X.B SMA Negeri 2 Baebunta, Kab. Luwu Utara, sebesar 91,7\% atau 33 dari 36 siswa termasuk dalam kategori tuntas dan 8,3\% atau 3 dari 36 siswa termasuk dalam kategori tidak tuntas. Hal tersebut menunjukkan bahwa motivasi dan hasil belajar sosiologi yang dicapai siswa Kelas X.B SMA Negeri 2 Baebunta sudah mengalami peningkatan pada siklus 1 dibandingkan sebelum tindakan.

Pada tabel 2.1 juga dapat dilihat peningkatan motivasi belajar siswa SMA Negeri 2 Baebunta, Kab. Luwu Utara, dari awal siklus 1 yang senang belajar sosiologi hanya 4 dari 36 siswa. Begitupun antusias siswa dari lembar pengamatan selama diskusi simposium yang diamati dari segi kemampuan menyampaikan Informasi, kemampuan mengajukan pertanyaan, dan kemampuan mengajukan argumentasi, kelancaran berbicara. Dari data hasil pengamatan tersebut dikemukakan bahwa dari 36 siswa, dengan skor total yang diperoleh adalah 68 , rata-rata 1,88 , persentase rata-rata motivasi belajar yaitu $62,9 \%$.

\section{Refleksi Siklus 2}

Pada siklus 2 perhatian dan keaktifan siswa semakin memperlihatkan kemajuan. Hal ini terjadi karena seringnya siswa menjawab pertanyaan dan menanggapi, serta berargumen sendiri. Rasa percaya diri siswa juga menunjukkan adanya peningkatan terlihat pada setiap pertemuan siswa tidak lagi malu-malu atau diam saja, akan tetapi berdasarkan observasi sebagian besar siswa telah termotivasi untuk belajar dengan penerapan metode diskusi simposium tersebut. Dengan diskusi simposium itu kemampuan siswa berpikir kritis dan mempertahankan pendapatnya juga lebih terlihat sehingga pemahaman siswa terhadap materi yang diajarkan semakin meningkat pula. Bahkan siswa berlomba-lomba untuk membacakan pemikirannya di depan teman-temannya untuk dibahas dan didiskusikan.

Secara umum motivasi dan hasil yang telah dicapai setelah pelaksanaan tindakan dengan penerapan metode diskusi simposium ini mengalami peningkatan, baik dari segi 
perubahan sikap siswa, keaktifan dan perhatian siswa maupun dari segi kemampuan siswa menjawab soal sosiologi melalui evaluasi setiap akhir siklus serta kemampuan mempertahankan argumentasinya. Sehingga tentunya telah memberikan dampak positif terhadap peningkatan motivasi belajar siswa kelas X.B SMA Negeri 2 Baebunta.

Dari tabel 1.3 diatas menunjukkan persentase ketuntasan belajar siswa kelas X.B SMA Negeri 2 Baebunta, Kab. Luwu Utara, sebesar 100\% atau semua nilai yang diperoleh siswa telah mencapai tuntas. Hal tersebut menunjukkan dengan penerapan metode diskusi simposium, maka akan meningkatkan motivasi dan hasil belajar sosiologi siswa Kelas X.B SMA Negeri 2 Baebunta, Kab. Luwu Utara.

Pada tabel 2.2 juga dapat dilihat peningkatan motivasi belajar siswa SMA Negeri 2 Baebunta, Kab. Luwu Utara, dari awal siklus 1 yang senang belajar sosiologi hanya 4 dari 36 siswa. Namun, terjadi peningkatan motivasi belajar pada siklus 2 tabel 2.2 karena sebanyak 32 siswa yang merasa senang dalam belajar sosiologi. Begitupun antusias siswa dari lembar pengamatan selama diskusi simposium yang diamati dari segi kemampuan menyampaikan Informasi, kemampuan mengajukan pertanyaan, dan kemampuan mengajukan argumentasi, kelancaran berbicara. Dari data hasil pengamatan tersebut dikemukakan bahwa dari 36 siswa, dengan skor total yang diperoleh adalah 68 , rata-rata 1,88 , persentase rata-rata motivasi belajar yaitu $62,9 \%$ pada siklus 1 . Ternyata terjadi peningkatan motivasi belajar siswa di siklus 2 dimana dari 36 siswa, skor total 99, rata-rata skor sebesar 2,75 serta persentase rata-rata motivasi belajar yaitu 91,6\%. Dari persentase rata-rata motivasi siklus 1 menuju ke siklus 2 mengalami peningkatan sebanayak $28,7 \%$.

Dilihat dari hasil pengamatan dan evaluasi, baik pada saat sebelum tindakan, maupun siklus 1 sampai siklus 2, terjadi peningkatan hasil dan motivasi belajar siswa SMA Negeri 2 Baebunta, Kab. Luwu Utara.

\section{KESIMPULAN}

Dari hasil penelitian yang dilakukan sebanyak dua siklus dapat disimpulkan bahwa:

1. Penerapan metode diskusi simposium dalam pembelajaran sosiologi pokok bahasan sosialisasi dapat meningkatkan motivasi belajar siswa kelas X.B SMA Negeri 2 Baebunta, Kab. Luwu Utara, semangat dan motivasi siswa meningkat terlihat ketika siswa berebutan menjawab pertanyaan, menanggapi dan mempertahankan jawaban, ini membuktikan ada peningkatan dalam kegiatan belajar mengajar dan evaluasi yang dilakukan mulai dari siklus I kemudian dilanjutkan siklus II yaitu : $91,6 \%-62,9 \%=28,7 \%$. 
2. Dengan penerapan metode diskusi simposium di kelas X.B SMA Negeri 2 Baebunta, Kab. Luwu Utara maka semangat belajar siswa semakin bertambah yang dibuktikan dengan banyaknya siswa yang sering berargumen dalam menyampaikan pendapat terhadap pokok permasalahan yang diberikan dalam proses diskusi simposium melalui kajian pustaka terlebih lagi melalui pengamatan lingkungan sekitar siswa.

3. Adapun kelebihan dari metode diskusi simposium yaitu siswa dapat ikut aktif dalam proses pembelajaran, hal lain siswa mampu berpikir kritis dari pada sebelumnya, sehingga suasana kelas menjadi lebih hidup.

\section{DAFTAR PUSTAKA}

Ahmadi, Abu. (2007). Sosiologi Pendidikan. Jakarta: Rieneka Cipta.

Ahmadi, Abu, \& Prasetya, Joko. (2005). Strategi Belajar Mengajar untuk Fakultas Tarbiyah Komponen MKDK. Bandung: Pustaka Setia.

Aqib, Zainal. (2007). Penelitian Tindakan Kelas untuk Guru. Bandung: YRAMA WIDYA.

Aqib, Zainal. (2008). Penelitian Tindakan Kelas untuk Guru. Bandung: YRAMA WIDYA

Departemen Pendidikan dan Kebudayaan. (1994). garis-garis Besar Program Pengajaran (GBPP).

Gunawan. Ary. (2000). Sosiologi Pendidikan. Jakarta: Rieneka Cipta.

Gintings, Abdokhman. (2008). Esensi Praktis Belajar dan Pembelajara. Bandung: HUMANIORA.

Hartomo. (2008). Ilmu Sosial Dasar. Jakarta: BUMI AKSARA.

Hasibuan. (2006). Proses Belajar Mengajar. Bandung: REMAJA ROSDA KARYA.

Herlina. (2008). Penerapan metode turnamen belajar untuk meningkatkan motivasi belajar kimia Siswa kelas XII IPA.5 SMA Negeri 11 makassar (Studi Pada Pokok Bahasan Reaksi Redoks dan Elektrokimia). Skripsi. Makassar: FMIPA UNM.

Kartono, kartini. (2005). Teori Kepribadian. Bandung: Mandar Maju.

(Kode PENDMIPA-0016). (2009). Skripsi : Upaya peningkatan prestasi belajar siswa melalui model kooperatif tipe STAD dengan pendekatan PAIKEM pada larutan elektrolit dan non elektrolit siswa kelas $X$ semester II SMA X, (http://gudangmakalah.blogspot.com/2009/08/skripsiupaya-peningkatan-presrasi.html. ) Diakses pada tanggal 17 Agustus 2010 pukul 09.23 WITA. Mustofa, Bisri, dkk. (2008). Kamus Lengkap Sosiologi. Jogjakarta: PANJI PUSTAKA.

Nasution. (2009). Sosiologi Pendidikan. Jakarta: Bumi Aksara.

Narwoko, Dwi. (2010). Sosiologi Teks Pengantar dan Terapan. JAKARTA: Prenada Media Group.

Rudyanto \& Saptra, Yudha. (2005). Pembelajaran Kooperatif Untuk Meningkatkan Keterampilan Anak. Jakarta: Departemen Pendidikan Nasional.

Suryosubroto. (2002). Proses Belajar Mengajar Di Sekolah. Jakarta: RINEKA CIPTA.

Sistem Pendidikan Nasional. (2003). Himpunan Perundang-Undangan Republik Indonesia. Bandung: Nuansa Aulia.

Solihatin, Etin. (2008). Cooperatif Learning (Analisis Pembelajaran IPS). Jakarta: BUMI AKSARA.

Sagala, Syaiful. (2006). Konsep dan Makna Pembelajarn. Bandung:ALFABETA.

Sahabuddin. (2003). Mengajar dan Belajar (dua aspek dari suatu proses yang disebut pendidikan. Ujung Pandang: Badan Penerbit Universitas Negeri Makassar.

Suhendi, Hendi. (2001). Pengantar Studi Sosiologi Keluarga. Bandung: PUSTAKA SETIA.

Trianto. (2007). Model Pembelajaran Inovatif Berorientasi Konstruktif. Jakarta: PRESTASI PUSTAKA

Taupan, Muhammad.(2008). Sosiologi Bilingual Untuk SMA Kelas X. Bandung: YRAMA WIDYA.

Winataputra, Udin. (2003). Strategi Belajar Mengajar. Jakarta. Pusat Penerbitan Universitas Terbuka. 
Yamin, Martinis. (2009). Profesionalisasi Guru dan Implementasi KTSP. Jakarta: Gaung Persada Press Jakarta.

Yamin, Martinis. (2006). Sertifikasi Profesi Keguruan di Indonesia. JAKARTA: Gaung Persada Press Jakarta.

Zarkasi, Firdaus. (2009). Belajar Cepat dengan Diskusi. Surabaya: Indah Surabaya. 